\title{
IMMUNOHISTOCHEMICAL INVESTIGATIONS OF P16 INK 4A EXPRESSION IN CARCINOMAS AND HIGH GRADE CERVICAL LESIONS
}

\author{
Milena Karcheva ${ }^{1}$, Savelina Popovska ${ }^{2}$, Rosen Nachev² \\ 1) Department of Epidemiology of Infectious Diseases, Faculty of Public Health, \\ Medical University - Pleven, Bulgaria \\ 2) Department of General and Clinical Pathology, University Hospital-Pleven, \\ Bulgaria
}

\section{SUMMARY:}

During the years the role of viruses as a cause of oncological illness was known. One of them is cervical carcinomas, related to Human Papilloma Viruses (HPV's). There are about 450000 new cases of cervical cancer worldwide each year, and 250000 deaths of this diagnosis. By the diagnosis cervical cancer gets there with two procedures: after mass screening or clinical suspicious for ill. By the availability apparent tumor diagnosis is put with biopsy. By the discreet lesions require utilization modern diagnostic methods. One of them is immunohistochemical method. In situ hybridization (ISH) assays for high-risk human papilloma virus (HR-HPV) and immunohistochemical (IHC) assays for surrogate markers such as $\mathrm{p} 16^{\text {INK }}{ }^{4 a}$ can be useful in detecting HR-HPV in cervical dysplasia. The aim of the following study was to find difference the level for expression of the tumor specific gene $\mathrm{p} 16^{\mathrm{INK}}{ }^{4 \mathrm{a}}$ in reactive, dysplastic and invasive changes in biopsy specimens from uterine cervix. In the lesions of the uterine cervix, over expression of p16 ${ }^{\text {INK }}$ 4a is induced by HPV and is associated with the process of cancerogenesis in the epithelium. Almost $100 \%$ of the high grade lesions and the invasive carcinomas demonstrated high level of expression of $\mathrm{p} 16^{\text {INK }}{ }^{4 a}$ while non dysplastic epithelium is always negative.

Key words: cervical carcinomas, human papilloma viruses, p16 INK4a expression,

\section{INTRADUCTION:}

Viruses have important meaning for human pathology. During the years the role of viruses as a cause of oncological illness was known. One of them is cervical carcinomas, related to Human papilloma viruses (HPV's). WHO Regional Office for Europe reported by cervix cancer morbidity. Data for selected countries are presented on fig.1. There are about 450000 new cases of cervical cancer worldwide each year, and 250000 deaths of this diagnosis. Every year new cases of cervical dysplasia, related to HPV's, are assess at 10 million cases with CIN II/III, 30 million cases with CIN I. Success in diagnostics of this dis- ease is due to the use of Pap-test /citological smear analysis/. However Pap-test gives significant portion of both false-positive and false-negative conclusions. Amendments of the diagnostic procedure are desirable. Aetiological role of papillomaviruses in cervical cancer is established while the role of cellular gene alterations in the course of tumor progression is less clear. Several research groups including us have recently named the protein $\mathrm{p} 16^{\text {INK }}$ 4a as a possible diagnostic marker of cervical cancer. To evaluate whether the specificity of $\mathrm{p} 16^{\text {INK }}{ }^{4 a}$ expression in dysplastic and neoplastic cervical epithelium is sufficient for such application we undertook a broader immunochistochemical registration of this protein with a highly specific p16 INK 4a monoclonal antibody.

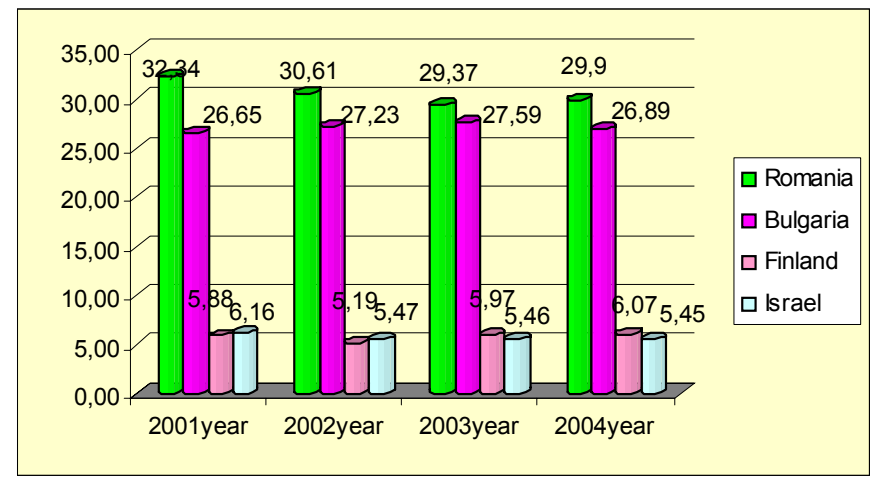

Fig. 1. Morbidity (\%000) by cancer of cervix in selected countries since 2001 for 2004 year.

AIM:

The aim of the following study was to find difference the level for expression of the tumor specific gene p16 INK 4a in reactive, dysplastic and invasive changes in biopsy specimens from uterine cervix.

\section{MATERIALS AND METHODS:}

Fifty six biopsy specimens were investigated in the following study. They were separated in four groups as follows: 
$1^{\text {st }}$ group - reactive non dysplastic changes $(n=13)$;

$2^{\text {nd }}$ group - different levels of dysplasia to $\mathrm{Ca}$ in situ $(\mathrm{n}=19)$

$3^{\text {rd }}$ group - invasive squamous cells carcinoma $(n=16)$

$4^{\text {th }}$ group - endocervical lesions - Microglandular hyperplasia, $\mathrm{Ca}$ in situ and invasive endocervical adenocarcinoma $(\mathrm{n}=8)$

Standard $4 \mu \mathrm{m}$ slides were stained with H\&E. An immunohistochemical method with monoclonal antibodies against the tumor-suppressor gene $\mathrm{p} 16^{\mathrm{INK}}$ 4a was applied on some specimens, according to the instructions provided by the manufacturer (DAKO). The evaluation of the positive immunohistochemical reactions for $\mathrm{p} 16^{\mathrm{INK}}$ 4a was also semiquantitative ( 0 when there is no positive reaction, 1+ from $15 \%$ to $20 \%$ staining of the nuclei and cytoplasm, $2+$ from $25 \%$ to $75 \%$ and $3+>75 \%$ ). Weak cytoplasm staining $(<5 \%)$ was considered negative. For statistical analysis of the results was used the method of correlative analyses and $\mathrm{c} 2$. Values of $\mathrm{p}<0.05$ were considered as statistically significant.

\section{RESULTS:}

The results from the expression of $\mathrm{p} 16^{\mathrm{INK}} 4 \mathrm{a}$ are presented in table 1 . In the cases with dysplastic lesions and invasive carcinomas was found strong correlation between the level of expression of $\mathrm{p} 16^{\text {INK }}{ }^{4 a}$ and the level of cervical neoplasia $(\mathrm{p}<0.01)$.

Tabl. 1. Grade of $\mathrm{p} 16^{\mathrm{INK} 4 \mathrm{a}}$ expression

\begin{tabular}{|l|c|c|c|c|c|}
\hline $\begin{array}{l}\text { Histological } \\
\text { diagnosis }\end{array}$ & $\mathbf{0}$ & $\begin{array}{c}\mathbf{1 +} \\
(<\mathbf{2 5} \%)\end{array}$ & $\begin{array}{c}\mathbf{2 +} \\
(\mathbf{2 5 - 7 5 \% )}\end{array}$ & $\begin{array}{c}\mathbf{3 +} \\
(\mathbf{7 5} \%)\end{array}$ & Total \\
\hline \begin{tabular}{l} 
1. Non-dysplastic lesions \\
\hline $\begin{array}{l}\text { Unmature squamous } \\
\text { metaplasia }\end{array}$
\end{tabular} & 5 & 0 & 0 & 0 & 5 \\
\hline $\begin{array}{l}\text { Atypical squamous } \\
\text { metaplasia }\end{array}$ & 1 & 0 & 0 & 0 & 1 \\
\hline Inflammation & 5 & 0 & 0 & 0 & 5 \\
\hline Inflammatory atypia & 2 & 0 & 0 & 0 & 2 \\
\hline 2. Dysplastic lesions & 1 & 2 & 0 & 0 & 3 \\
\hline C I N I & 1 & 2 & 5 & 0 & 8 \\
\hline C I N II & 0 & 0 & 1 & 7 & 8 \\
\hline C I N III & 0 & 0 & 1 & 15 & 16 \\
\hline $\begin{array}{l}\text { Invasive squamous } \\
\text { carcinomas }\end{array}$ & 2 & 0 & 0 & 0 & 1 \\
\hline $\begin{array}{l}\text { Microglandular } \\
\text { hyperplasia }\end{array}$ & 0 & 0 & 2 & 0 & 1 \\
\hline $\begin{array}{l}\text { Endocervical } \\
\text { dysplasia }\end{array}$ & 0 & 0 & 0 & 5 & 5 \\
\hline $\begin{array}{l}\text { Endocervical } \\
\text { carcinomas }\end{array}$ &
\end{tabular}

All 13 cases $(100 \%)$ of non dysplastic cervical lesions are negative for $\mathrm{p} 16^{\text {INK }}$ 4a (fig.2). The most cases of CIN III group (7cases-87,5\%) showed strong (+++) cytoplasmic and nuclear expression of p16 ${ }^{\text {INK }}$ 4a in the whole depth of the epithelium (fig. 3,4). Strong mainly nuclear everexpression was found in all invasive cervical adenocarcinomas. (fig. 5).

\section{DISCUSSION:}

In the lesions of the uterine cervix, overexpression of p16 INK 4a is induced by HPV and is associated with the process of cancerogenesis in the epithelium. These observations show that, the $\mathrm{p} 16^{\mathrm{INK}} 4 \mathrm{a}$ immunostaining can make easier the precise identification of displastic cervical epithelial cells on histological specimen. It displays the cellular changes in the infected cell, as a result of the genomic integration of the viral oncogenes. Because of the fact that overexpression is not found in normal, non- transformed cells $\mathrm{p} 16^{\mathrm{INK}}$ 4a is reliable marker for identification of dysplastic and malignant epithelium. Almost 100\% of the high grade lesions and the invasive carcinomas demonstrated high level of expression of $\mathrm{p} 16^{\mathrm{INK}}$ 4a while non displastic epithelium is always negative.

\section{CONCLUSION:}

This statistically significant different expression of p16 ${ }^{\text {INK }}{ }^{4 a}$, in different types of lesions in the uterine cervix, contributes for their identification and makes this marker helpful and objective for the diagnosis of the cervical pathology. So far no indications for a difference in the $16^{\mathrm{INK} 4 \mathrm{a}}$ staining pattern of cervical lesions caused by different HR-HPV types have been found. The velocity of neoplastic transformation seems to be different for different HR-HPV types, but once the oncogene products of HRHPV have caused cell cycle disturbances, as one of the first steps in carcinogenesis, overexpression of $\mathrm{p} 16^{\mathrm{INK} 4 \mathrm{a}}$ should be detectable independent of the individual HR-HPV type.

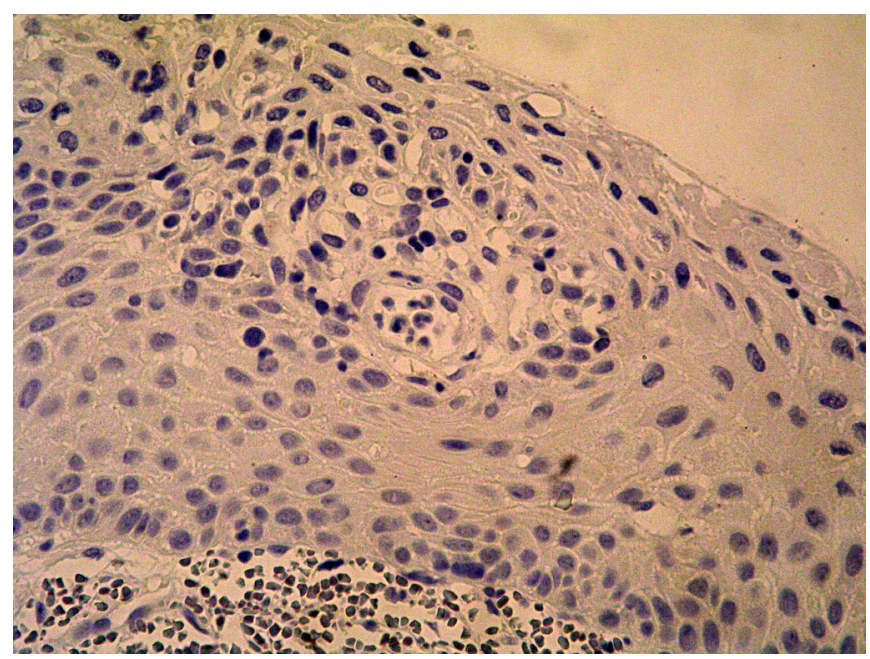

Fig. 2. Non dysplastic lesion negative for $\mathrm{p} 16^{\mathrm{INK}} 4 \mathrm{a}$ 


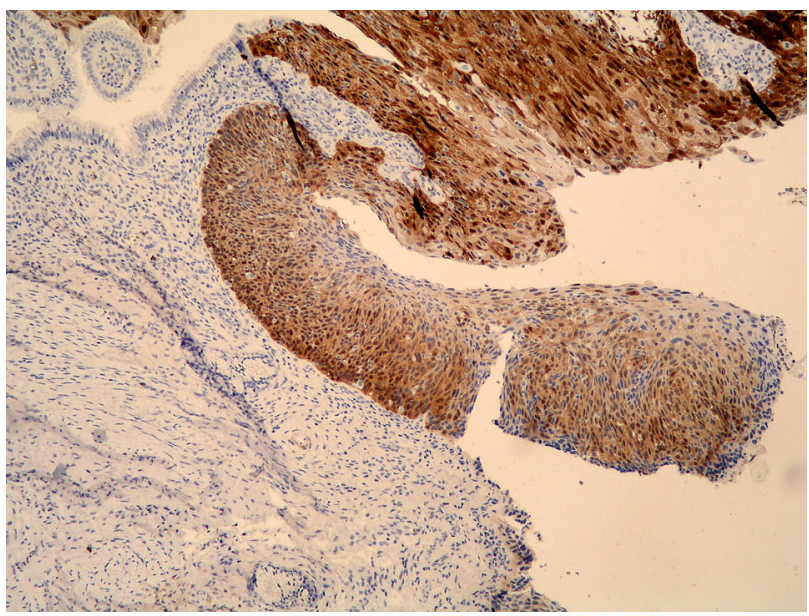

Fig. 3 CIN III - expression of p16 INK 4a

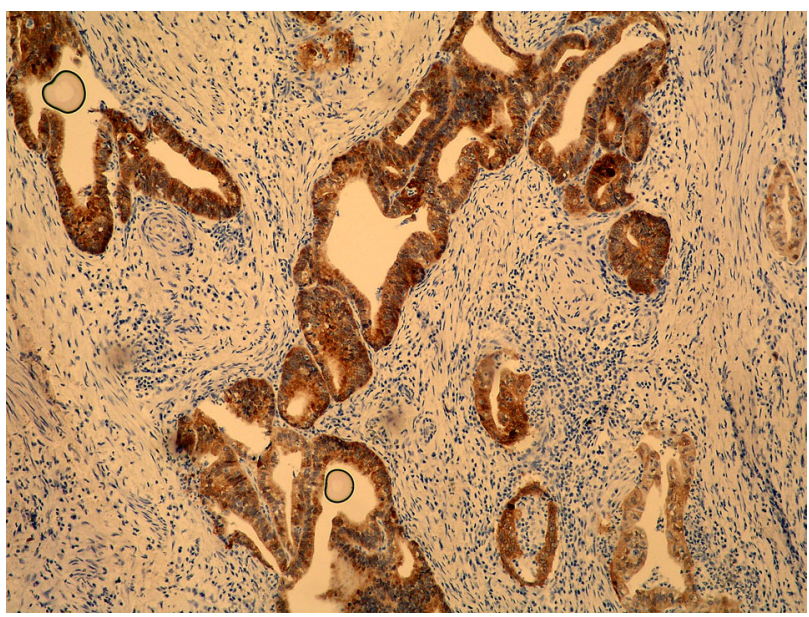

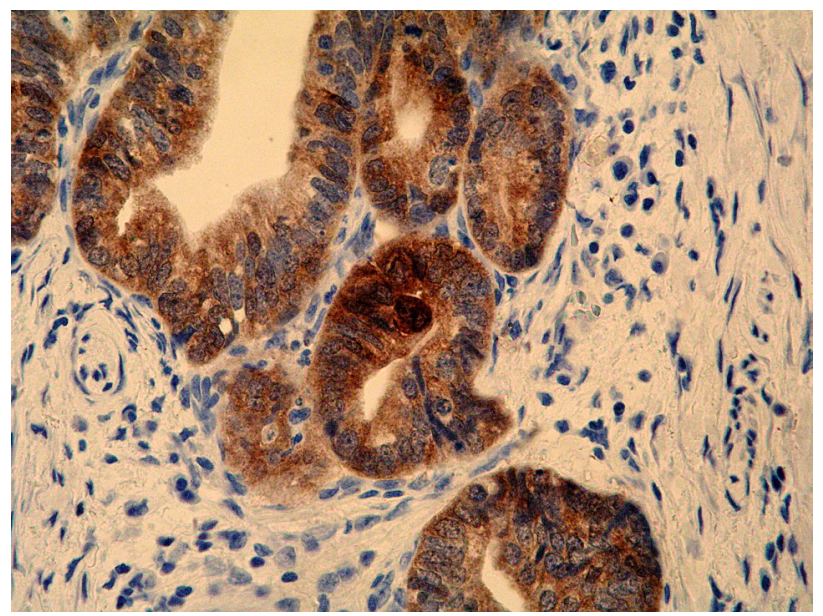

Fig. 4 Adenocarcinoma in situ - expression of p16 ${ }^{\text {INK } 4 a}$

Fig. 5 Invasive cervical adenocarcinoma - expression of p16 ${ }^{\text {INK } 4 a}$

\section{REFERENCES}

1. Carozzi F, Cecchini S, Confortini M, Becattini V, Cariaggi MP, Pontenani G, et al. Role of P16(INK4a) expression in identifying CIN2 or more severe lesions among $\mathrm{HPV}$-positive patients referred for colposcopy after abnormal cytology. Cancer. 2006 Apr;108(2):119-23. [PubMed]

2. Giannoudis A, Herrington CS. Human papillomavirus variants and squamous neoplasia of the cervix. J Pathol. 2001 Mar; 193(3):295-302. [PubMed]

3. Holladay EB, Logan S, Arnold J, Knesel B, Smith GD. A comparison of the clinical utility of p16(INK4a) immunolocalization with the presence of human papillomavirus by hybrid capture 2 for the detection of cervical dysplasia/neoplasia. Cancer. 2006 Dec;108(6):451-61. [PubMed]

4. Kalvatchev Z, Draganov P. Human
Papiloma Viruses and Malygnancy, Clin Appl Immunol. 2004 Sep;3(2):361-365

5. Keating JT, Ince T, Crum CP. Surrogate biomarkers of HPV infection in cervical neoplasia screening and diagnosis. $A d v$ Anat Pathol. 2001 Mar;8(2):83-92. [PubMed]

6. Klaes R, Friedrich T, Spitkovsky D, Ridder R, Rudy W, Petry U, et al. Overexpression of p16(INK4A) as a specific marker for dysplastic and neoplastic epithelial cells of the cervix uteri. Int J Cancer. 2001 Apr;92(2):276-84. [PubMed]

7. Negri G1, Egarter-Vigl E, Kasal A, Romano F, Haitel A, Mian C. p16INK4a is a useful marker for the diagnosis of adenocarcinoma of the cervix uteri and its precursors: an immunohistochemical study with immunocytochemical correlations. Am J Surg
Pathol. 2003 Feb;27(2):187-93. [PubMed]

8. Sano T, Oyama T, Kashiwabara K, Fukuda T, Nakajima T. Expression status of p16 protein is associated with human papillomavirus oncogenic potential in cervical and genital lesions. Am J Pathol. 1998 Dec;153(6):1741-8. [PubMed]

9. Sano T, Oyama T, Kashiwabara K, Fukuda T, Nakajima T. Immunohistochemical overexpression of $\mathrm{p} 16$ protein associated with intact retinoblastoma protein expression in cervical cancer and cervical intraepithelial neoplasia. Pathol Int. 1998 Aug;48(8):5805. [PubMed]

10. zur Hausen H. Papillomavirus infections -- a major cause of human cancers. Biochim Biophys Acta. 1996 Oct;1288(2): F55-78. [PubMed]

\section{Address for correspondence:}

Dr. Milena Karcheva; Department of Epidemiology of Infectious Diseases, University of Medicine; 1 "St. Kliment Ohridsky" Str., 5000 Pleven, Bulgaria E-mail: milena_karcheva@abv.bg 